Article

\title{
Poverty Alleviation and Microfinance for the Economy of Pakistan: A Case Study of Khushhali Bank in Sargodha
}

\author{
Stylianou Tasos 1,*®D, Muhammad Ijaz Amjad ${ }^{2}$, Masood Sarwar Awan ${ }^{3}$ and Muhammad Waqas ${ }^{3}$ \\ 1 Department of Economics, International Hellenic University, Dimitriou Poliorkitou 65, \\ PC 54633 Thessaloniki, Greece \\ 2 Higher Education Department, Government of the Punjab, Punjab 54000, Pakistan; mijazaslam@yahoo.com \\ 3 Department of Economics, University of Sargodha, Punjab 40100, Pakistan; awan811@hotmail.com (M.S.A.); \\ muhammad.waqas@uos.edu.pk (M.W.) \\ * Correspondence: tasosstylianou@gmail.com
}

Received: 15 June 2020; Accepted: 22 July 2020; Published: 10 August 2020

check for updates

\begin{abstract}
Poverty is a universal reality, and no one can deny the omnipresence of it all over the world. It is considered as the most harmful economic and social problem of human beings since their creation. It affects individuals as well as society as a whole in a very destructive way, and it is considered that poverty is the mother of all human rights violations. Perhaps no one would argue against the notion that microfinance can be a very useful apparatus in human, social, economic, political and national development. Microfinance has been established to fill the gap of a missing credit market for the poor. Among all other anti-poverty strategies, it has become one of the most important and successful tools for poverty elimination throughout the world. In this study, we investigate the impact of microfinance on poverty alleviation for the economy of Pakistan. The literacy is very poor for the area of Pakistan, so our research will help policy makers in making the right decisions in order to help the people that are living below the poverty line. Primary data of 300 households from Khushhali Microfinance Bank Limited were collected. The findings reveal that microfinance imparts a vital role in poverty eradication where the poverty level has decreased from $42.67 \%$ in comparison household $(\mathrm{CHH})$ to $29.33 \%$ in the program household (PHH). Finally, it unveils the fact that there is a negative association between the provision of microfinance and poverty level of the household. The availability of micro financing facilities to the poor has declined the poverty rate from 42.67 percent to 29.33 percent. The Logistic Regression model implies that poverty has a negative association with the duration of microfinance, education and existence of a market in the locality, whereas it is positively related to family size and gender of the respondent.
\end{abstract}

Keywords: macroeconomics; poverty; microfinance; Pakistan

JEL Classification: F41; E60; I38

\section{Introduction}

Poverty is a universal reality, and no one can deny the omnipresence of it all over the world. It has various types and facets in different parts of the world. In the present scenario, poverty works as a breeding ground for clashes among the people. Poverty is taken as the most harmful economic and social problem of human beings since their creation. It affects individuals as well as society as a whole in a very destructive way and it is considered that poverty is the mother of all human rights violations. In the modern age, poverty has become a gigantic problem of the world. It is not only an obstacle 
in the economic development of the country but it also hinders human development. Generally, it is defined as deprivation of well-being.

According to the World Bank, poverty is a multi-facet phenomenon that is about insufficiency or lack of political, economic, cultural and social entitlements. Similarly (Alkire and Foster 2011) define that it is an insufficient income or lack of means with which to satiate basic needs. Furthermore, there are numerous indicators of poverty like hunger, low income and unavailability of shelter, sickness and lack of knowledge, poor health, unemployment and powerlessness, no freedom to speech and vote and lack of clean drinking water. In addition, there are also some other factors that trap the people into poverty such as political instability, gender disparities, big family size, natural disaster, corruption, socio-economic and regional disparities. So, poverty eradication is not only a developmental goal, but it is also a main threat to human life in the 21st century. It is imperative to think about a tool that can uplift the income level of the poor, reduce their vulnerability and boost their self-confidence while devising an anti-poverty policy. In this context, microfinance is often recommended as a solution to multiple social problems and ultimately will lead to the economic development of a country (Balamurugan and Selvaraj 2014).

Microfinance has brought a positive impact to the life of clients, boosted the ability of poor individuals to improve their conditions and others have indicated that poor people have taken advantage of increased earnings to improve their consumption level, health and build assets Ebimobowei et al. (2012). Today, microfinance is increasingly becoming an important investment opportunity, mainly in developing regions such as Latin America and Africa, and all major international institutions, like the European Union, the United Nations, the World Bank, the Asian Bank, and the American Development Bank dedicate funding and research to microfinance. The relationship between microfinance and poverty is still in question and this paper provides some new empirical evidence on the poverty-reducing effects of microfinance.

In some countries, microfinance in general can be seen as a political tool, where the politicians often intervene in favor of individuals who are struggling to repay their loans during times of economic stress. Microfinance can be an appropriate solution against financial and social exclusion by ensuring the availability of suitable loans, savings and other financial products or services. In this perspective, we should keep in mind that while "there is no internationally accepted definition of microfinance", the term is generally used to indicate a range of financial services/products (of small amounts) offered to low-income/non-bankable customers and microenterprises. Microfinance targets those individuals who are denied credit by formal financial and banking institutions because of financial illiteracy or lack of knowledge of the formal rules that they should follow to access credit provided by these institutions (Leone and Porretta 2014).

Lack of or limited access to credit is a main hurdle behind the sea of poverty. Generally, in developing countries both formal and informal financial sectors have failed to provide financial services to the destitute people. Collateral requirements, preference for rich people, large amount of loans and tedious bureaucratic processes exclude the low income people from the banking sector. Similarly, the informal financial sector has also denied providing credit to the poor due to a very high rate of interest and exploitation (Chaudhry 2009). Hence, microfinance has been established to fill the gap of the missing credit market for the poor. It has tackled the collapse of the conventional banking sector by extending micro loans to poor needy people for earning a livelihood. Microfinance assists the poor by raising income, providing access to education and self-empowerment. Among all other anti-poverty strategies, microfinance has become one of the most important and successful tools for poverty elimination throughout the world (Chughtai et al. 2015).

Since the creation of Pakistan in 1947, poverty has been the most challenging issue. The poverty trend in Pakistan has been fluctuating heavily over time. According to Pakistan's Economic Survey (Government of Pakistan 2016), 29.50 percent of the population is living below the poverty line. In Pakistan, most of the people are residing in villages and their livelihood is based on the agricultural sector of the economy. Specifically, rural people are living in a very pathetic condition due to a shortage 
of basic facilities like drinking water, basic education, health facility, roads, energy, communication and unemployment.

In Pakistan, poverty can be said as double edge razor because, on the one hand, poor people have low income while, on the other hand, they cannot access basic requirements of life like clean drinking water, basic education, health facilities and sanitation. The objective of our research is to investigate the role of micro financing initiated by Khushhali Microfinance Bank Limited (KMBL) for poverty mitigation in the district of Sargodha. The literacy is very poor for the area of Pakistan so our research will help policy makers in making the right decisions in order to help the people that are living below the poverty line. Summarizing all the above, the current study is trying to investigate the role of microfinance in poverty elimination. Moreover, we are trying to determine the contribution of microfinance in the lessening of poverty according to the poverty status of households. We also try to investigate the relation between poverty, family size, existence of schools in the locality and duration of microfinance. There is a growing debate as to the best strategy for alleviating global poverty. Our study attempts to shed light on microfinance focusing on the districts of Pakistan. The poverty trend in Pakistan has been fluctuating heavily over time and is one of the major problems not only for Pakistan but also for the entire world. The governments should be informed about all of the available strategies for alleviating property, and microfinance is considered as one of the best tools in the hands of policy makers. The next section provides a review of the relevant literature on microfinance, especially its effect on poverty reduction at the macro level. Methodology specifications and data are discussed in Section 3. Section 4 shows the analyses and empirical results. The final section offers concluding observations.

\section{Literature Review}

In the literature, there is a broad convergence, both academic and that produced by the international institutions involved in economics, finance and development, in that microfinance today is essentially facing two challenges. On the one hand, it must be more and more sustainable, economically and financially. On the other hand, it must increase the outreach to have a more significant effect on the development processes in poorer areas of the world (Cull et al. 2011; Bogan 2012; Leone and Porretta 2014).

Over the past decade, the microfinance universe has undergone several changes (Leone and Porretta 2014). Generally, microfinance is associated with developing countries, where large segments of the population need to access these types of financial services; however, microfinance includes a number of activities that extend to developed countries too, where- especially after the international economic and financial crisis-an increasing number of people deal with poverty issues due to factors such as immigration, unemployment, inactivity and marginalization.

According to La Torre (2006) the lack of access to finance, especially for self-development or social advancement purposes, may lead to impoverishment and worsen a 'vicious circle of poverty'. When people in poor countries have low income levels, thus low savings and low capital accumulation, their productivity and growth are limited. Meanwhile, the ultimate benefit of microfinance is to endeavor to reverse this trend into low income, injection of credit, investment, more income, more savings, more investment, more income.

Provision of credit to the low income people without any collateral was a daunting task for the financial sector. However, in 1983, Dr. Mohammad Yunus came up with a revolutionary idea of nipping this issue in the bud with the establishment of Grameen Bank (GB) in Bangladesh. He believed that "credit is a fundamental human right". Thus, Dr. Mohammad Yunus is known as the pioneer of the notion of microfinance in the present era. According to him, five percent of credit users get rid of poverty in Bangladesh per year (Yunus 2001). Now microfinance is being taken as an effective device for getting rid of poverty from the world.

The utilization of microfinance reduces poverty and vulnerability as well. Zaman (2000) deployed a study to check the degree to which micro credit eliminated poverty and vulnerability by a case study 
of Bangladesh Rural Advancement Committee (BRAC). The empirical findings of the study were that micro credit had played its role in eradicating income poverty and vulnerability. Adeola (2000) also explained that microfinance is one of the most effective tools that successfully eliminates poverty. Microfinance has a significant impact on income of the borrower households. Park and Ren (2001) found that there is a positive link between credit and income of the household in China. Along with provision of microfinance, a good anti-poverty policy and strategy is very imperative. Robinson (2001) explained this fact that microfinance could be a tool of anti-poverty strategy by reviewing the policies. Provision of microfinance could lead to a reduction in poverty while a lack of access to credit triggers poverty. The study observed a positive relationship between micro credit and the income of the destitute people.

Bhatt and Tang (2001) explained that the need of micro credit was increasing in poor nations due to the rise in the poverty level. Thus, microfinance institutions should spread out their facilities to the area where the problem of poverty emerges. The microfinance sector should introduce different financial products to satiate the need of a poor man to earn more fame and to compete with the conventional banking industry. Mayoux (2001) explored that microfinance had played a positive and defining role for women empowerment, health facilities, and child education and for other socio-economic factors of the poor community. In a similar research, Simanowitz (2003) concluded that with the help of a microfinance program there was an improvement in economic conditions of the borrower families and almost half of these clients were able to raise their income above minimum income level. Weiss et al. (2003) argued that the revolution of microfinance had changed the mindset of people for helping the poor all over the world. The poor people could get access to the credit market with the inception of the microfinance program.

Mohammad and Mohammed (2007) investigated the effect of microfinance on the borrowers in Bangladesh. The aim of this study was to analyze the working of microfinance in the context of poverty alleviation and 109 clients were interviewed. The collected data were analyzed by different statistical techniques like percentage, correlation, ANOVA, and regression analysis. The outcomes demonstrated that micro credit has raised the living standard of the clients. It helped the poor to get rid of poverty by economically empowering them.

Swain and Floro (2012) observed the role of microfinance on poverty eradication and vulnerability of the destitute people in India. The prime purpose of the study was to investigate whether microfinance can lead to reduced vulnerability as well as poverty of the lower income people. The results showed that the members of SHG were no more vulnerable as compared to non-members and the incidence of poverty is also found high in non-member people. So, microfinance had played a positive role in the reduction of poverty and vulnerability as well. The effective utilization of microfinance is also attached with the provision of basic infrastructure. Ebimobowei et al. (2012) observed the relationship between microfinance and the eradication of poverty in the Bayelsa State of Nigeria. The findings showed that there was a positive association between microfinance and poverty eradication. The study also revealed the fact that only the availability of microfinance could not eliminate poverty without the provision of basic infrastructures. Therefore, it is recommended by the study that the governments of developing countries like Nigeria should also focus on the provision of basic infrastructure along with micro financing. Kireti and Sakwa (2014) analyzed the socio-economic effect of the microfinance program on women in Nakuru County, Kenya. The data of 370 women clients were taken by using a structured questionnaire. The study showed that the availability of a micro credit facility raised income and expenditure on education and health facilities. Miled and Rejeb (2015) made an effort to explore the relationship between micro credit and poverty alleviation by collecting the data from 596 microfinance institutions (MFIs). The findings showed that a country with high level of microfinance provision had less poverty and a higher level of per capita income.

In Pakistan, microfinance has also earned great popularity among the public as well as policy makers fighting against poverty. Therefore, different studies have been designed to investigate the impact of microfinance on poverty eradication over time. Adil and Hammad (2003) observed 
a relationship between micro credit and agri production in the area of district Dera Ghazi Khan. The findings showed that micro credit had a positive impact on agri production. Ahmad et al. (2004) examined the effectiveness of the microfinance program initiated by Khushali Microfinance Bank Limited (KMBL) for poverty eradication in Tehsil Rahim Yar Khan, Pakistan. The findings of the study showed a positive link between credit and income, credit and saving, credit and yield per acre, credit and assets formation and credit and farm expenses. It was concluded that (KMBL) Rahim Yar Khan was efficiently working to serve the poor and assisting them to come out of poverty.

Lodhi et al. (2006) devised the study to evaluate the micro credit program carried out by NRSP. The findings showed that NRSP was playing a vital role in empowering females. It also boosted the living standard of women in the community. Chaudhry (2009) argues that the microfinance program is a very effective tool to fight against poverty in Southern Punjab, Pakistan. However, he concludes that these activities can be made more useful by ensuring macroeconomic stability in the country. Saboor et al. (2009) observed the nexus between microfinance and poverty reduction in Pakistan. They gave empirical evidences that microfinance helped to raise the income of the clients. Ayuub (2013) made an effort to analyze the role of microfinance in the fight against poverty in the Bahawalpur District. The study focused on the impact of the microfinance scheme started by the National Rural Support Program (NRSP) in this area. It was observed that microfinance had a significant impact on poverty reduction in that area. The empirical findings also revealed that microfinance policy uplifted the living standard of poor people and helped them to develop their business. The study suggested to increase the loan size and the SBP should support and regulate MFIs to provide credit facilities to the poor people on reasonable terms and conditions.

Alam et al. (2014) tried to establish a relationship of microfinance initiated by PRSP with social and economic position of rural poor farmers in Gujranwala. He concluded that micro credit was playing a vital role for these poor farmers. Imtiaz et al. (2014) examined the part of microfinance in poverty elimination in the Faisalabad district. The data had been collected by using a household survey method from the borrowers of Khushhali Microfinance Bank Limited (KMBL), district Faisalabad. The findings showed that microfinance had reduced poverty. Saad et al. (2014) examined the social and economic effects of microfinance on the agricultural sector in district Multan. The prime objective was to explore the economic and social effects of micro financing on the life of formers and to point out the factors that compel farmers in debt. The sample of the study was comprised of the clients of ZTBL. Systematic random sampling was deployed to retrieve the data of 120 borrowers. The result revealed that the provision of microfinance led to improvement in the productivity of farmers and increased their livelihoods.

After examining the literacy on microfinance and poverty, the conclusion is that microfinance is one of the most important and effective tools being used for poverty alleviation all over the world nowadays. The results of some studies may differ from one another due to different methodologies deployed in different studies. Also, all the above selected studies are analyzed because they are studying countries or areas that have common characteristics for poverty and microfinance programs like Pakistan. All these studies and their results will help us to compare our research. Some studies take a different line in that the fruit of microfinance are spoiled by high rates of interest, low levels of infrastructure and small scale businesses. While most of the studies depict the same picture that microfinance helps the poor to come out of poverty, increase their income and consumption, enable them to have better education and health facilities and raise their standard of living. This research is designed to analyze the contribution made by the microfinance program initiated by KMBL in poverty reduction in the area of district Sargodha.

Among all other microfinance initiatives, Khushhali Microfinance Bank Limited (KMBL) has been performing its functions since 2000 in different parts of Pakistan. The prime purpose of KMBL is to provide financial assistance to micro-enterprises in Pakistan. The microfinance program initiated by KMBL has a considerable effect on poverty eradication all over Pakistan. There are different studies like (Ahmad et al. 2004; Akram and Hussain 2011; Imtiaz et al. 2014; Iqbal et al. 2015; Mahmood et al. 2016) 
that have been conducted along with KMBL and reveal that microfinance provided by KMBL has a positive impact on the poverty level of the poor client. Micro financing has helped them to get rid of this curse and overall poverty has come down. In the district of Sargodha there is a large network of micro financing. According to the Pakistan Microfinance Network (2017), the Sargodha district stands among the top three districts with an 11.11 percent increase in micro credit outreach all over Punjab by the end of 2016. In Sargodha, KMBL has three branches (Bhalwal, Sargodha, and Sahiwal) to provide micro financing facilities.

\section{Data and Methodology}

In this section, we analyze the techniques and methods we used in order to show the role of microfinance in poverty elimination in the area of district Sargodha. The proposed research is based upon the primary data of the borrowers of Khushhali Microfinance Bank Limited, collected from the district of Sargodha. Per capita income has been used as a proxy for poverty by different studies such as (Asghar 2012; Waheed 2009). Keeping in view the above research, the current study also used per capita income as a proxy for poverty. Similarly, in this research, the duration of microfinance is marked as a proxy for microfinance as used by Chowdhury and Alam (2008). The designed study categorized the household into two types.

a. Program household; those households that have received more than one loan from KMBL.

b. Comparison household; those households that have applied for microfinance and yet have to receive their first loan.

\subsection{Data Sources}

In researches related to poverty, a household survey is the main tool for data collection and it is used at a national as well as international level. According to Deaton (1997), household data have been used in almost all the poverty-oriented studies. This research is using the household survey method as used by Jegede et al. (2011) in Nigeria to analyze the effect of microfinance on poverty alleviation.

\subsection{Questionnaire}

The current study has formulated two different well-organized close ended types of questionnaires for data collection. The first questionnaire is for the comparison of households and it includes questions about households and locality level characteristics of $\mathrm{CHH}$ (comparison household). Whereas the second questionnaire has been designed for program households and it comprises household, locality level and microfinance characteristics of PHH (program household). The researchers have conducted face to face interviews for filling out the questionnaires.

\subsection{Sampling Technique}

In this study, a Probability Proportional to Size Sampling technique (PPS) was used for sample selection. PPS is a method of sampling in which units are sampled on the basis of probability proportional to their size. Also, it is used in a targeted population when different units vary in size. In this situation an ideal solution is to assign probability proportional to their size so that larger units may have greater contribution to total sample size. In this way, the selected sample would have more efficient estimates. In the district of Sargodha, Khushhali Microfinance Bank Limited have three branches: Bhalwal, Sahiwal, and Sargodha and the total active borrowers were 13,031 in 2017. The share of each branch to total active clients is given by Table 1.

Thus, by using the probability to size sampling technique, we have 60 percent weight to Sargodha, 30 percent to Bhalwal and 10 percent to the Sahiwal branch. The primary data of 300 households were collected from all the three branches of KMBL operating in district Sargodha during March-April 2018, out of which 150 households belong to comparison household ( $\mathrm{CHH}$ ) and 150 to Program Household (PHH). 
Table 1. Distribution of borrowers.

\begin{tabular}{ccc}
\hline Branch (KMBL) & Date of Establishment & Active Borrowers (2017) \\
\hline Sargodha & 2003 & 7818 \\
Bhalwal & 2008 & 3909 \\
Sahiwal & 2015 & 1303 \\
\hline
\end{tabular}

Source: Khushhali Microfinance Bank Limited.

\subsection{Poverty Line}

The poverty line is a cut-off point in which below that point a person is considered to be poor. Basically, poverty line is the measure of lowest acceptable level of income or consumption that splits the poor from non-poor (Anyanwu 2004). In the case of developing nations, the absolute poverty line is more useful and relevant than relative poverty line because most people there are living below the poverty line (World Bank 2011).

Historically, Pakistan has been using a food energy intake (FEI) method to check poverty estimations. By deploying this approach and the poverty line of 2259.44 (PKR) per adult per month, poverty in Pakistan declined from 29.33 percent in 1998-1999 to 9.33 percent in 2013-2014. The poverty estimation of 9.33 percent looks very skeptical in a country like Pakistan. Hence, to tackle this issue, Pakistan Planning Commission adopted a new methodology that is based on the cost of basic needs (CBN) approach. CBN has the following advantages.

1. It is very transparent.

2. It is often used in developing countries.

3. This covers non-food expenditure as well.

Hence, in 2016, the poverty line was revised to 3030.32 (PKR) per person per month and the proposed research has used this national poverty line for poverty estimation as given by the Pakistan Economic Survey (Government of Pakistan 2016).

\subsection{Methodology of Binary Logistic Regression}

Logistic regression is a suitable regression technique to carry out when the outcome variable is categorical in nature. Binary logistic regression technique (BLR) is deployed to investigate the relationship between a binary response variable and a set of explanatory variables. When our dependent variable is dichotomous or categorical, the assumption of linearity in a normal regression analysis is violated. To tackle this issue, binary logistic regression deploys logarithmic transformation on an outcome variable. In this way, logistic regression describes the multiple linear regression equation in a logarithmic term, which is known as logit.

A logit model is a logarithmic transformation of probability or natural log of the ratio of probability. A logit model defines the conditional probability of a dependent variable. The literature reveals that for poverty estimation, the logit and Probit model has been extensively used by different studies such as (Apata et al. 2010; Awan et al. 2011; Chowdhury and Alam 2008). According to Gujarati and Porter (2009), the logit model is more reliable, normal and efficient. The logit model is widely recognized because it gives more rigorous outcomes.

\section{Assumption of Binary Logistic Regression}

There are the following three assumptions.

1. The outcome variable must be dichotomous;

2. The relationship between the dependent and explanatory variables must be non-linear;

3. The error term should not be normally distributed. 
In our study, the outcome variable (poverty) is a binary or dichotomous variable, with (0) if the household is non-poor and with (1) if the household is poor. So, all the above conditions are satisfied in the present study and that is why binary logistic regression analysis is deployed in this research as used by Chowdhury and Alam (2008).

\subsection{Construction of Variables}

We are treating poverty as the outcome variable. While household, locality wise and microfinance characteristics of the borrowers are used as explanatory variables.

The proposed research has conducted two different types of analysis. The first approach is based upon descriptive and graphical analysis, whereas the second approach is about econometric analysis (BLR). All variables, which are used in both types of analysis in order to investigate the effectiveness of microfinance in poverty eradication in the area of the district of Sargodha, are given by Tables 2 and 3.

Table 2. Variables of descriptive and graphical analysis.

\begin{tabular}{cc}
\hline Variable & Explanation \\
\hline Poverty Status of PHH and CHH & Poor or Non-Poor \\
\hline Gender of Respondent & Male or Female \\
\hline Educational Status of Respondent & Literate or Illiterate \\
\hline Family Size of Respondent & Minimum, Maximum, Mean \\
\hline Economic Characteristics of Household (AMFI, AMFEEX, \\
AMFHEX, AMFSAV, AMFEX) & Measured in Pak-Rupees \\
\hline Locality Level Characteristics (ESHL, SGC, EMKT, MTROD) & Yes or No \\
\hline Duration of Microfinance (Percentage) & Loan Period (1, 2,3, .. 5 or above) \\
\hline Reasonable Interest Rate (RIR) & Yes or No \\
\hline Loan Helped in Changing Economic Condition (LHCEC) & Yes or No \\
\hline Wish for another Loan (WFAL) & Yes or No \\
\hline Loan invested in the Sector (Trading, Manufacturing, Services, \\
Live Stock, Others) & Yes or No \\
\hline Loan Amount (PKR) & Minimum, Maximum, average \\
\hline
\end{tabular}

Table 3. Variables of the logistic regression analysis.

\begin{tabular}{|c|c|}
\hline Variable & Explanation \\
\hline POVT & $\begin{aligned} & =1 \text { if household is poor } \\
= & 0 \text { if household is non-poor }\end{aligned}$ \\
\hline GEN & Gender of the respondent \\
\hline EDU & $\begin{array}{l}=1 \text { if respondent is literate } \\
=0 \text { if respondent is illiterate }\end{array}$ \\
\hline FSZ & Family size of the respondent \\
\hline ESHL & $\begin{array}{l}=1 \text { if a school exist in the locality } \\
\quad=0 \text { if a school do not exist }\end{array}$ \\
\hline EMKT & $\begin{array}{l}=1 \text { if market exist in the locality } \\
=0 \text { if market does not exist }\end{array}$ \\
\hline TRAD & $\begin{array}{c}=1 \text { if loan is invested in trading sector } \\
=0 \text { if loan is not invested in trading sector }\end{array}$ \\
\hline MANU & $\begin{aligned} & =1 \text { if loan is invested in manufacturing } \\
= & 0 \text { if loan is not invested in manufacturing }\end{aligned}$ \\
\hline SERV & $\begin{array}{l}=1 \text { if loan is invested in services sector } \\
=0 \text { if loan is not invested in services sector }\end{array}$ \\
\hline OTHER & $\begin{aligned} & =1 \text { if loan is invested in other sector } \\
= & 0 \text { if loan is not invested in other sector }\end{aligned}$ \\
\hline DOMF & Duration of Microfinance \\
\hline
\end{tabular}

Table 2 incorporates all the variables included in descriptive analysis. Our research explores the characteristics of beneficiaries of a microfinance program and makes a comparison between the program 
household (PHH) and comparison household $(\mathrm{CHH})$ to analyze the effectiveness of microfinance in poverty eradication with the help of descriptive analysis.

Table 3 presents the variables that are included in the econometric analysis to examine the impact of microfinance on poverty eradication and to identify the occupational sectors that have more positive contribution towards poverty alleviation in the area of the district of Sargodha.

\subsection{Construction of Econometric Model}

The study has formulated two different econometric models for empirical analysis.

\subsubsection{Model One}

This model is used to investigate the impact of microfinance on poverty eradication in the area of district Sargodha.

$$
\begin{gathered}
Y=\alpha+\beta_{1} F S Z+\beta_{2} E S H L+\beta_{3} D O M F+\mu \\
Y=\text { outcome for the household } \\
F S Z=\text { family size of the household } \\
E S H L=\text { existence of school in the locality } \\
D O M F=\text { duration of microfinance of the borrowers } \\
\mu=\text { error term of the model } \\
\left(\alpha, \beta_{1}, \beta_{2}, \beta_{3}\right)=\text { the parameters to be estimated }
\end{gathered}
$$

Now this model is converted into a logistic regression model by applying the following mathematical procedure.

The general function is given as below:

$$
Y=\alpha+\beta_{1} X_{1}+\beta_{2} X_{2}+\beta_{3} X_{3}
$$

where $X s$ represent independent variables as

$$
\begin{gathered}
X_{1}=\text { Family Size }(F S Z) \\
X_{2}=\text { Existence of School in the Locality }(E S H L) \\
X_{3}=\text { Duration of Microfinance }(D O M F) \\
Y=\text { Poverty }(\text { POVT })
\end{gathered}
$$

A household is considered poor with a value of (1), if its per capita income is less than 3030.32 (PKR) and non-poor with a value of (0), if per capita income is greater than 3030.32 (PKR).

$$
\begin{gathered}
\alpha=\text { intercept of the equation } \\
\beta_{i}=\text { coefficient of the explanatory variables }
\end{gathered}
$$

As we know, logit is the logarithmic transformation of probability or natural log of the ratio of probabilities. It can be expressed as follows

$$
\begin{gathered}
\operatorname{Logit}(Y)=\ln \left[\frac{\text { Probability of happening of an event }}{\text { Probability of not happening of an event }}\right] \\
\text { Logit }(Y)=\ln \left[\frac{p}{1-p}\right] \\
p=\text { probability of happening of an event } \\
1-p=\text { Probability of not happening of an event }
\end{gathered}
$$


To get logistic regression model, Equation (2) is put into the right hand side of Equation (4).

$$
\ln \left[\frac{p}{1-p}\right]=\alpha+\beta_{1} X_{1}+\beta_{2} X_{2}+\beta_{3} X_{3}
$$

\subsubsection{Tests Performed}

According to Menard (1995), the overall robustness of the model is tested through likelihood ratio statistics, which is based on chi square. The author shows that the model is fitted well and predictors have a statistically significant impact on the outcome variable. The Cox and Snell $\mathrm{R}$ Square works as a pseudo $\mathrm{R}^{2}$, which shows how much variability can be explained by the model. Furthermore, $\mathrm{R}^{2}$ does not represent the same sense in BLR as in linear regression. Gujarati and Porter (2009) explain that goodness of fit of the model is not very important in BLR, whereas the signs of estimated coefficient and their practical and statistical significance matter a lot.

\section{Results and Discussion}

Table 4 explains the classification of poverty status of comparison households as well as program household by duration of microfinance. The table shows that program households of Khushhali Microfinance Bank Limited divest from poverty as duration of microfinance increases. As per depiction, without participating in the microfinance program, $42.67 \%$ comparison households are poor. However, after participating in micro financing activities, the poverty status of the program household is declining along with increasing duration of microfinance, while on the other hand, the non-poor percentage of borrower households is also increasing. In membership duration of 12-24 months, the poverty status of the program household has declined to 37.33 percent and non-poor percentage has increased to 62.72 percent. Similarly, the poverty status of the program household is declining with an expanding period of membership in the microfinance program. Finally, in a membership period of above 60 months, just 15 percent of program households are poor, which indicates that almost 28 percent less poor are in program households as compared to the comparison household.

Table 4. Poverty status of the household.

\begin{tabular}{ccc}
\hline Variable & Percentage of Poor & Percentage of Non-Poor \\
\hline Comparison Household & 42.67 & 57.35 \\
Program Household & & \\
12-24 (months) & 37.33 & 62.72 \\
25-36 (months) & 33.91 & 66.17 \\
37-48 (months) & 28.84 & 71.21 \\
49-60 (months) & 26.97 & 73.19 \\
Above 60 months & 15 & 85 \\
\hline
\end{tabular}

Source: Author's own calculations.

Overall, poverty rate has declined from 42.67 percent in $\mathrm{CHH}$ to 29.33 percent in $\mathrm{PHH}$. This difference between poverty status of the comparison household and program household reveals that microfinance significantly eradicates poverty of borrower households. So, this reduction in poverty status shows the effectiveness, viability, as well as significance of a microfinance program initiated by KMBL in the area of district Sargodha.

Figure 1 supports the result we have established in the above table. The graph shows that as the duration of micro financing is increasing, the number of poor households is decreasing, while the number of non-poor households is increasing. The graph reveals the fact that provision of microfinance leads to a reduction in poverty. Thus, microfinance has an effective contribution in poverty alleviation in the district of Sargodha. 


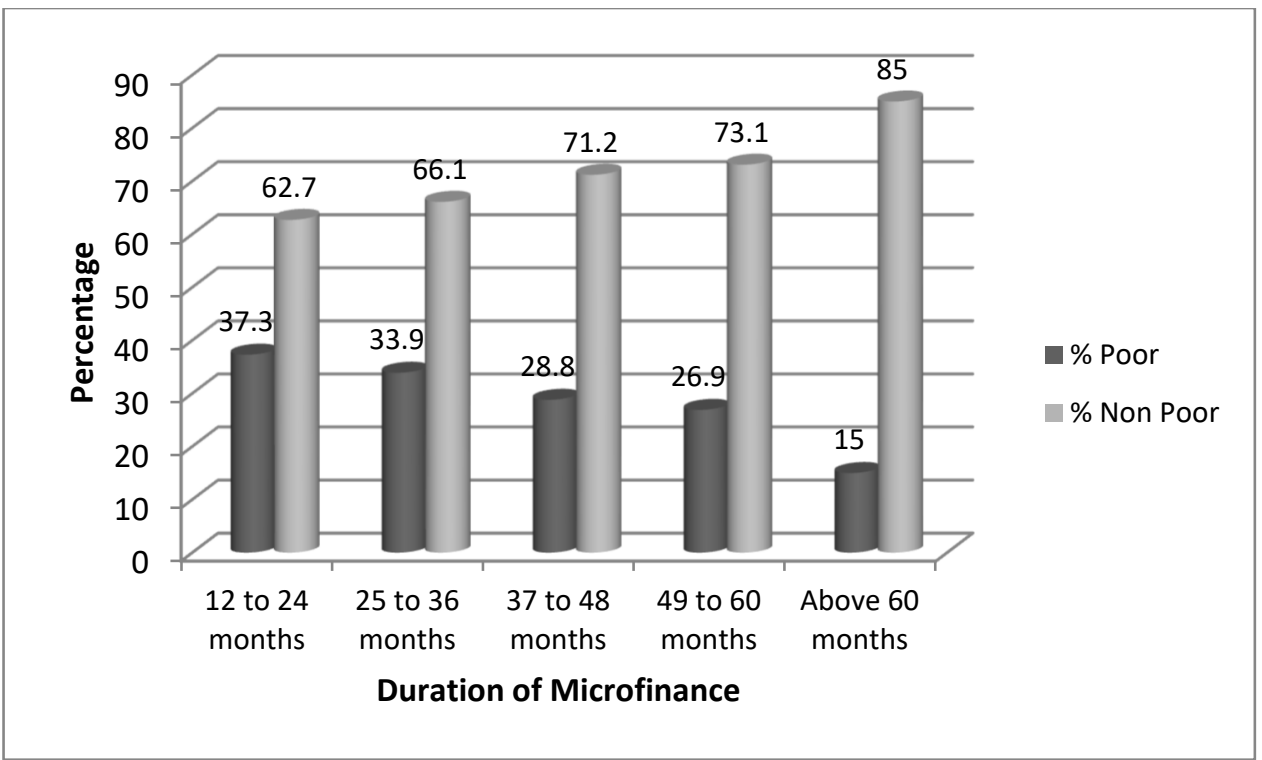

Figure 1. Poverty status of the household. Source: Author's own calculations.

Table 5 shows the distribution of the respondents by their gender. As per the table, 70.74 percent were males and just 29.326 percent were females. Whereas, in program households, the share of females in beneficiaries of micro financing has increased to 34.63 percent and male's share has squeezed to 65.37 percent.

Table 5. Gender of the respondent (Percentage).

\begin{tabular}{ccc}
\hline Gender & Comparison Household & Program Household \\
\hline Male & 70.74 & 65.37 \\
Female & 29.26 & 34.63 \\
\hline
\end{tabular}

Source: Author's own calculations.

Table 6 reveals the distribution of borrowers' household by duration of microfinance. The depiction reveals mostly borrowers, i.e., 36 percent of the total borrowers are in between the period 12-24 months. Twenty percent of borrowers are in 25-36 months. Just eight percent of the total borrowers took a five year loan. The last category depicts that 19.30 percent of borrowers got a loan above six years.

Table 6. Duration of microfinance of the borrower (percentage).

\begin{tabular}{cc}
\hline Period (Month) & Percentage \\
\hline $12-24$ & 36 \\
$25-36$ & 20 \\
$37-48$ & 16.70 \\
$49-60$ & 8 \\
Aвоvе 60 & 19.30 \\
\hline Source: Author's own calculations.
\end{tabular}

Figure 2 classifies the borrowers by their duration of microfinance. According to the figure, 36 percent of borrowers are availing their two years loan. Twenty percent and 16.70 percent borrowers are in 25-36 months and 37-48 months, respectively. Just eight percent are taking a five year loan and 19.30 percent of total borrowers are above 60 months. 


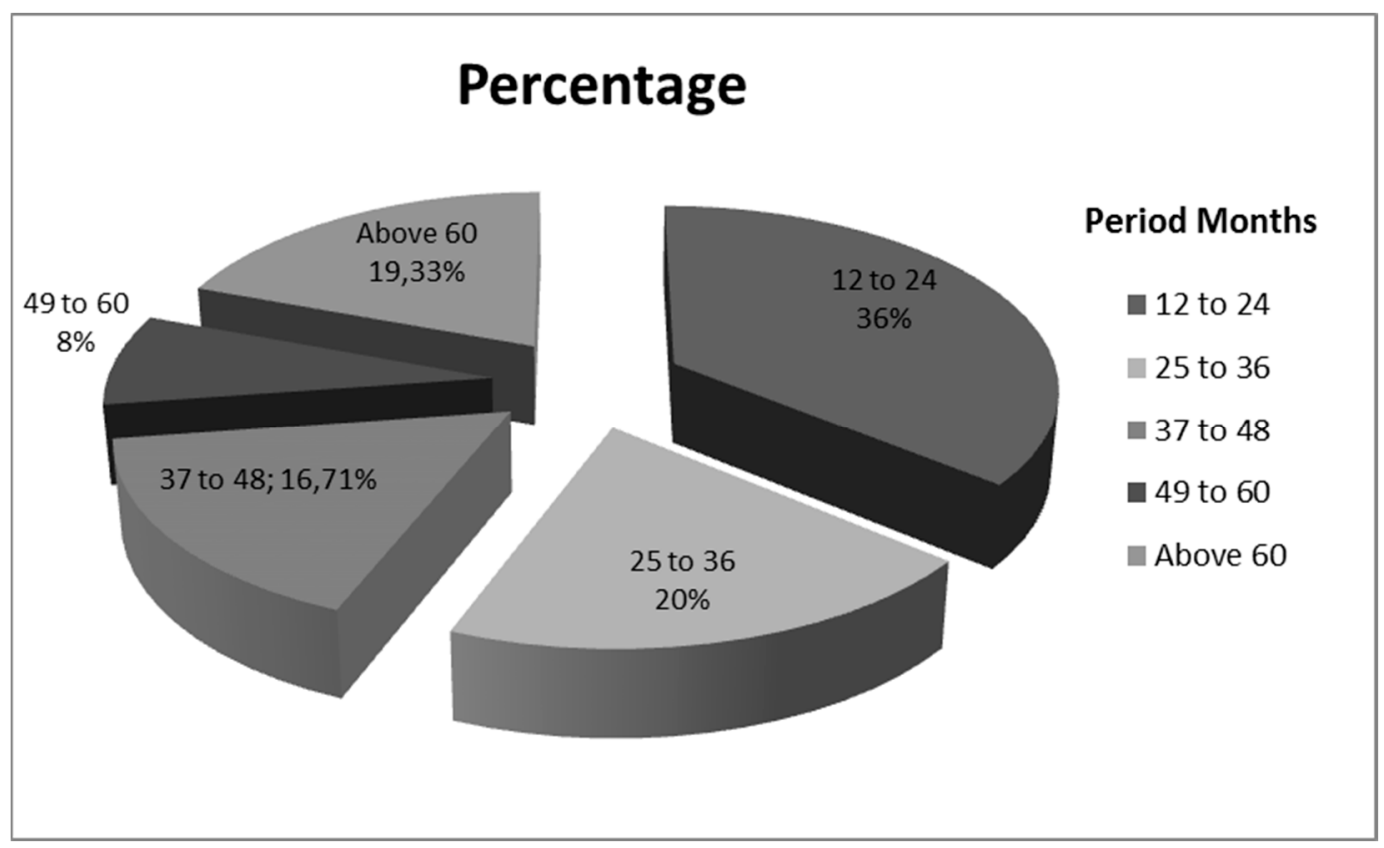

Figure 2. Duration of microfinance of the borrower (percentage). Source: Author's own calculations.

Table 7 depicts the response of the borrowers to three different variables (reasonable interest rate (RIRI), loan helped in changing their economic condition (LHCEC) and wish for another loan (WFAL)). The findings reveal that a big percentage of the respondents, i.e., $71.30 \%$, are not satisfied with the rate of interest charged by KMBL. Higher cost of borrowing impedes the borrower from using the fund in the most effective way. The high rates of interest, surge cost of borrowing, complicate the repayment schedule and their inefficiency to manage or inability to utilize the amount of loan are major reasons of default. The fruit of microfinance are highly sensitive to the interest rate. It has a vital role in determining the effectiveness of microfinance in poverty reduction. The poor are taking micro loans and investing them in small enterprises. Their small businesses are already operating at an inefficient level and when a high rate of interest is charged, it becomes very difficult for the borrowers to ripen the fruit of microfinance in an appropriate way. Ninety-five percent of the borrowers replied that microfinance has played a key role in uplifting their economic status. According to results, 90 percent of the borrowers want to take another loan.

Table 7. Response of the client (RIR, LHCEC, WFAL).

\begin{tabular}{cc}
\hline Variable & Percentage \\
\hline RIR & \\
Yes & 28.7 \\
No & 71.3 \\
LHCEC & \\
Yes & 95 \\
No & 5 \\
WFAL & \\
Yes & 90 \\
No & 10 \\
\hline Source: Author's own calculations.
\end{tabular}

Table 8 shows the distribution of different sectors according to their share in total loan invested. The results reveal that almost half of the loans (48.70\%) are being invested in the livestock sector. Fourteen percent (14\%), 9.30 percent, 18 percent and 10 percent are being invested in trading, manufacturing, services and other sectors, respectively. Thus, a major share of the total loans is going to the live stock sector, which reveals that most borrowers are attached with the agricultural sector. 
Table 8. Loan invested in the sector.

\begin{tabular}{cc}
\hline Variable & Percentage \\
\hline Trading & 14 \\
Manufacturing & 9.30 \\
Services & 18 \\
Live Stock & 48.70 \\
Others & 10 \\
\hline Source: Author's own calculations.
\end{tabular}

Source: Author's own calculations.

Figure 3 explains the fact that most of the loans are being allocated for livestock purposes. Just 9.3 percent is invested in the manufacturing sector. So, most of the borrowers want to invest in the livestock sector instead of other sectors like trading, manufacturing and services.

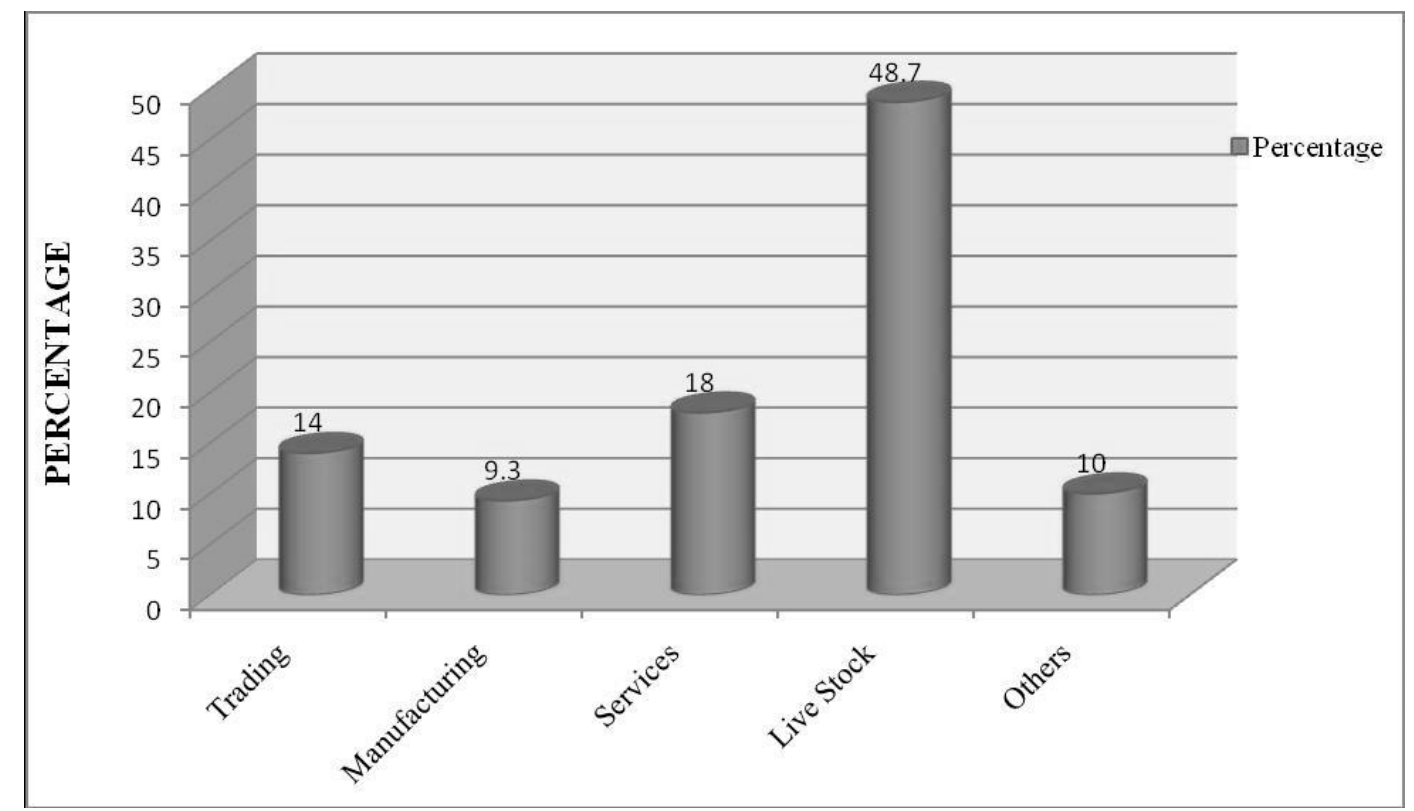

Figure 3. Loan invested in the sector. Source: Author's own calculations.

Table 9 explains the characteristics of loan amounts taken by the borrowers of Khushhali Bank Limited. The minimum amount of loan is 20,000 PKR whereas 147,000 PKR is the maximum amount taken by the borrowers. The mean of the loan extended by KMBL to its clients is 37,083.40 PKR.

Table 9. Loan Amount (amounts in PKR).

\begin{tabular}{cccc}
\hline Variable & Minimum & Maximum & Mean \\
\hline Loan Amount & 20,000 & 147,000 & $37,083.40$ \\
\hline & Source: Author's own calculations.
\end{tabular}

\subsection{Econometric Analysis}

The impact of microfinance on poverty eradication is investigated using binary logistic regression on model one. In this model, poverty is the dependent variable whereas family size, existence of school in the locality and duration of microfinance are independent variables.

The below table (Table 10) presents the estimated parameters (log odds) of the binary logistic regression. The interpretation of the estimated coefficient in logistic regression is very similar to the linear regression. It shows the change in the logit (log odds) of the outcome variable due to one unit change in the predictor. The logit of the outcome variable is obtained by simply taking the natural log of the odds of $(\mathrm{Y})$ occurring. The standard errors of these estimated coefficients have been given in 
the column labeled (S.E). $p$-value of the corresponding parameters is given in the column labeled as $p$-value in the table.

Table 10. Estimates of binary logistic regression.

\begin{tabular}{ccccc}
\hline Variable & Coefficient & S.E & $p$-Value & Odds Ratio \\
\hline FSZ & 0.31 & 0.10 & $0.002^{*}$ & 1.37 \\
ESHL & -1.67 & 0.48 & $0.000^{*}$ & 0.19 \\
DOMF & -0.41 & 0.15 & $0.008^{*}$ & 0.66 \\
CONSTANT & -0.61 & 0.80 & 0.450 & 0.54
\end{tabular}

Note. $-2 \mathrm{LL}=150.454$, Cox and Snell R Square $=0.18$, Chi-Square $=31.079$, Probability $=0.000 .{ }^{*}(1 \%$ level $)$.

One of the most important advantages of binary logistic regression is that its coefficients (log odds) can be interpreted in terms of odds ratios. It is very difficult to interpret the coefficient (log odds) of BLR. Therefore, they are exponentiated to convert into odds ratios, as depicted in the column odds ratio, and can be interpreted as change in probability or odds of outcome variable due to one unit change in predictor. If the value of odds ratio exceeds 1 , then the probability of an outcome occurring increases along with an increase in the predictor, and if the value of odds ratio is less than 1 , then the probability of an outcome occurring decreases along with an increase in the predictor. In the regression, a 95\% confidence interval is taken and it is calculated for the odd ratios for the significant risk factors.

The empirical outcomes of the study reveal that the sign of family size is positive and its $p$-value is (0.003), which means it is highly significant at $1 \%$ level. The odds ratio is higher than 1 , implying that if family size increases by one unit, the odds of being poor will also rise by 1.37 times. This finding is the same as (Asghar 2012; Waheed 2009).

The existence of a school in the locality has a negative and significant impact on poverty. The value of the odds ratio is less than 1, meaning that if a locality has a school, the probability of being poor among the residents of that area would be less as compared to the locality that does not have a school. This finding indicates that when people have access to education, their likelihood of being poor decreases because with the help of education they can unleash their potential and earn their livelihood easily. So, the results are consistent with (Omoniyi 2013; Pervez 2014).

The table shows that there is a negative association between provision of microfinance and poverty. The Duration of Microfinance (DOMF) has a negative sign and its $p$-value is $(0.008)$, which indicates that it is statistically significant at the $1 \%$ level. The results show that as the duration of microfinance increases, the poverty level of the borrower households decreases. The value of odds ratio is also less than 1, implying that as the membership period of microfinance increases, the odds of being poor decreases.

In the research literature, it is concluded that microfinance assists the poor in coming out of poverty by providing them a wide series of financial products. The poor people can unleash their potential with the help of micro financing and can get rid of poverty. The outcomes of the current study are also consistent with the other studies like (Ahmad et al. 2004; Ayuub 2013; Jegede et al. 2011; Chaudhry 2009; Fareed et al. 2004; Ghalib et al. 2015).

According to Menard (1995), overall robustness of the model is tested through likelihood ratio statistics, which is based on chi square. In the present study, the value of chi square is 31.079 and its $p$-value is (0.000). It shows that the model is a good fit and predictors have a statistically significant impact on the outcome variable. The Cox and Snell $R$ Square works as a pseudo $\mathrm{R}^{2}$, which shows how much variability, can be explained by the model. Furthermore, $\mathrm{R}^{2}$ does not represent the same sense in BLR as in linear regression. Gujarati and Porter (2009) explain that goodness of fit of the model is not very important in BLR, whereas the signs of the estimated coefficient and their practical and statistical significance matter a lot. 


\subsection{Limitations of the Research}

This empirical study has two limitations. Firstly, the scope of the investigation was only Pakistan. Therefore, in terms of external validity in generalizing the behavior for all countries is still questionable. Secondly, the findings of this study depend largely on the respondent's honesty and integrity. However, if the respondent's answers were biased towards more socially desirable answers, the findings will also indicate bias.

\section{Conclusions and Policy Recommendations}

The current study investigates the role of micro financing in poverty elimination. Perhaps no one would argue against the notion that microfinance can be a very useful apparatus in human, social, economic, political and national development. Primary data of the clients of KMBL operating in district Sargodha have been analyzed by deploying both descriptive as well as econometric techniques (BLR). On the basis of empirical evaluation, it is very easy to determine that microfinance has a vital and noteworthy contribution to the lessening of poverty.

According to the descriptive statistics, it is more than obvious that program households of Khushhali Microfinance Bank Limited divest from poverty as duration of microfinance increases. Without participating in the microfinance program, 42.67\% comparison households are poor. However, after participating in micro financing activities, the poverty status of program households declines along with an increase in the duration of microfinance, while on the other hand, the non-poor percentage of borrower households also increases. So, this reduction in poverty status shows the effectiveness, viability, as well as significance of the microfinance program initiated by KMBL in the area of district Sargodha. As the duration of micro financing increases, the number of poor households decreases, while the number of non-poor households increases. Thus, microfinance has an effective contribution to poverty alleviation in district Sargodha.

One other important finding is that a large number of respondents, i.e., $71.30 \%$, are not satisfied with the rate of interest charged by KMBL. Higher cost of borrowing impedes borrowers from using the fund in the most effective way. The high rates of interest, surge cost of borrowing, complicate the repayment schedule and their inefficiency to manage or inability to utilize the amount of loan are major reasons of default. The fruits of microfinance are highly sensitive to the interest rates. We can say that it has a vital role in determining the effectiveness of microfinance in poverty reduction. The poor are taking micro loans and investing them in small enterprises. Their small businesses are already operating at an inefficient level and when a high rate of interest is charged, it becomes very difficult for the borrowers to ripen the fruit of microfinance in an appropriate way.

The study unveils the fact that there is a negative association between provision of microfinance and poverty level of the household. With the availability of micro financing facilities to the poor, the poverty rate has come down from 42.67 percent to 29.33 percent. Hence, almost 14 percent of the borrower households have got rid of poverty by availing micro financing.

Also, our outcomes reveal that the sign of family size is positive, the odds ratio is higher than 1 , implying that if family size increases by one unit, the odds of being poor will also rise by 1.37 times. This finding is the same as Asghar (2012) and Waheed (2009). Moreover, the existence of schools in the locality has a negative and significant impact on poverty. The value of odds ratio is less than 1 , meaning that if a locality has a school, the probability of being poor among the residents of that area would be less as compared to a locality that does not have a school. This finding indicates that when people have access to education, their likelihood of being poor decreases because with the help of education they can unleash their potential and earn their livelihood easily. Our results are consistent with Omoniyi (2013) and Pervez (2014). Also, we have similar results with the studies conducted by Simanowitz (2003), Weiss et al. (2003) and Chaudhry (2009). In the research literature, it is concluded that microfinance assists the poor in coming out of poverty by providing them a wide series of financial products. The poor people can unleash their potential with the help of micro financing and can get rid of poverty. The outcomes of the current study are also consistent with the other studies like 
Ahmad et al. (2004), Ayuub (2013), Jegede et al. (2011), Chaudhry (2009), Fareed et al. (2004) and Ghalib et al. (2015).

Although the microfinance program has played a key role to combat poverty in the district of Sargodha, this scheme is not a silver bullet that can be a panacea for the impoverished people, because poverty is a multidimensional and very complex phenomenon. The relationship between microfinance and poverty is not so simple, which is why microfinance should be used very consciously. Microfinance is not a miracle solution. It is not for everyone and is not solely responsible for poverty alleviation. Microfinance must also be coupled with other social programs that are flexible to meet the diverse needs of destitute families. The effectiveness of microfinance can be enhanced by simultaneously taking some other steps. Therefore, along with the provision of microfinance services to the poor people, subsequent policy measures are suggested for policy makers and Khushhali Microfinance Bank Limited to use microfinance as a valuable tool in poverty reduction. There is a need to minimize the interest rate and the cost of borrowing must be reduced to a minimum. Special attention should be given to educating the borrowers to utilize loans in a better way.

Author Contributions: Writing-original draft preparation, S.T. Conceptualization, I.A., M.S.A. and M.W.; methodology, M.W.; software, M.S.A. and M.W.; validation, S.T., I.A., M.S.A. and M.W.; data curation, S.T., I.A., M.S.A. and M.W.; writing — review and editing, S.T.; visualization, S.T., I.A., M.S.A. and M.W. All authors have read and agreed to the published version of the manuscript.

Funding: This research received no external funding.

Conflicts of Interest: The authors declare no conflict of interest.

\section{References}

Adeola, Fola. 2000. Entrepreneurial Skills, Job Creation, and Poverty Reduction in Nigeria. Lagos: AIESEC Annual Alumni Lecture.

Adil, Sultan Ali, and Badar Hammad. 2003. Impact of micro-credit on poverty alleviation and agricultural production: A case study of NRSP, D.G. Khan Region, Pakistan. Journal of Agricultural Research 41: 309-16.

Ahmad, Shahzad, Muhammad Sajid Naveed, and Abdul Ghafoor. 2004. Role of microfinance in alleviating rural poverty: A case study of khushhali bank program in Rahim Yar Khan, Pakistan. International Journal of Agriculture and Biology 6: 426-28.

Akram, Muhammad, and Imtiaz Hussain. 2011. The role of microfinance in uplifting income level: A study of district Okara, Pakistan. Interdisciplinary Journal of Contemporary Research in Business 2: 83-94.

Alam, Muhammad, Raza Ullah, Ali Iqtidar Mirza, Waqar Saleem, Mehboob Elahi, and Hamid Sultan. 2014. Impact of microcredit scheme on socio-economic status of farmers (a case study of PRSP in district Gujranwala). A Research Journal of South Asian Studies 29: 161-69.

Alkire, Sabina, and James Foster. 2011. Understandings and misunderstandings of multidimensional poverty measurement. Journal of Economic Inequality 9: 289-314. [CrossRef]

Anyanwu, C. M. 2004. Microfinance institutions in Nigeria: Policy, practice and potential. Paper presented at G24 Workshop on Constraints to Growth in Sub Saharan Africa, Pretoria, South Africa, November 29.

Apata, T. G., O. M. Apata, O. A. Igbalajobi, and S. M. O. Awoniyi. 2010. Determinants of rural poverty in Nigeria: Evidence from small holder farmers in south-western, Nigeria. International Journal of Science and Technology Education Research 1: 85-91.

Asghar, Nadia. 2012. Micro financing for poverty reduction: An empirical study of rural areas of tehsil Gujrat, Pakistan. International Journal of Advances in Management and Economics 1: 14-19.

Awan, Masood Sarwar, Nouman Malik, Haroon Sarwar, and Muhammad Waqas. 2011. Impact of education on poverty reduction. International Journal of Academic Research 3: 659-64.

Ayuub, Sunia. 2013. Impact of microfinance on poverty alleviation: A case study of NRSP in Bahawalpur of Pakistan. International Journal of Academic Research in Accounting, Finance and Management Sciences 3: 119-35.

Balamurugan, P., and D. A. Selvaraj. 2014. Microfinance and poverty alleviation: An analysis with SHGs contribution. International Journal for Research in Management and Pharmacy 3: 7-14.

Bhatt, Nitin, and Shui-Yan Tang. 2001. Delivering microfinance in developing countries: Controversies and policy perspectives. Policy Studies Journal 29: 319-33. [CrossRef] 
Bogan, Vicki L. 2012. Capital structure and sustainability: An empirical study of microfinance institutions. The Review of Economics and Statistics 94: 1045-58. [CrossRef]

Chaudhry, Imran Sharif. 2009. Poverty alleviation in Southern Punjab, Pakistan: Empirical evidence from the project area of Asian development bank. International Research Journal of Finance and Economics 23: $23-32$.

Chowdhury, M., and Jahangir Alam. 2008. Poverty and microfinance: An investigation into the role of microcredit in reducing the poverty level of borrowing households in Bangladesh and the Philippines. The Whitehead Journal of Diplomacy and International Relations 9: 19-35.

Chughtai, Muhammad Waqas, Muhammad Fazal Zaheer, and Sania Taj. 2015. Effectiveness of micro financing for poverty alleviation: A case study of Tameer microfinance bank. Research Journal of Economis E Business Studies 4: 91-99.

Cull, Robert, Asli Demirguc-Kunt, and Jonathan Morduch. 2011. Does Regulatory Supervision Curtail Microfinance Profitability and Outreach? World Development 39: 949-65. [CrossRef]

Deaton, Angus. 1997. The Analysis of Household Surveys-A Microeconometric Approach to Development Policy. Baltimore: Johns Hopkins University Press.

Ebimobowei, Appah, John M. Sophia, and Soreh Wisdom. 2012. Analysis of Microfinance and poverty reduction in Bayelsa State of Nigeria. Arabian Journal of Business and Management Review 1: 38-57.

Fareed, Z., F. Shahzad, M. Arshad, R. N. Lodhi, and U. E. Amen. 2004. The impact of microfinance on poverty reduction (a case study of Okara, Southern Punjab, Pakistan). European Academic Research 1: 3196-217.

Ghalib, Asad K., Issam Malki, and Katsushi S. Imai. 2015. Microfinance and household poverty reduction: Empirical evidence from rural Pakistan. Oxford Development Studies 43: 84-104. [CrossRef]

Gujarati, Damodar N., and D. C. Porter. 2009. Basic Econometrics, 5th ed. New York: McGraw-Hill.

Imtiaz, Aisha, Hafiz Zahid Mehmood, Mehmood Hafiz, Zahid Mehmood, Waqar Akram, and Muhammad Irfan. 2014. Impact of microfinance on poverty reduction: A case study of district Faisalabad. Journal of Economics and Sustainable Development 5: 60-65.

Iqbal, Zahid, Shahid Iqbal, and Muhammad Ahmad Mushtaq. 2015. Impact of microfinance on poverty Alleviation: The study of district Bahawal Nagar, Pakistan. Management and Administrative Sciences Review 4: 487-503.

Jegede, Charles A., James Kehinde, and Babatunde Hamed Akinlabi. 2011. Impact of microfinance on poverty alleviation in Nigeria: An empirical investigation. European Journal of Humanities and Social Sciences 2: 97-111.

Kireti, Grace Wakio, and Maurice Sakwa. 2014. Socio-economic effects of microfinance services on women: The case of rosewo microfinance, Nakuru County, Kenya. International Journal of Academic Research in Economics and Management Sciences 3: 43-59. [CrossRef]

La Torre, Mario. 2006. A new conception of microfinance. In Microfinance. London: Palgrave Macmillan, pp. 1-19. Leone, Paola, and Pasqualina Porretta. 2014. Microcredit Guarantee Funds in the Mediterranean: A Comparative Analysis. Berlin/Heidelberg: Springer.

Lodhi, Toheed Elahi, Muhammad Luqman, A. S. I. F. Javed, and Muhammad Asif. 2006. Utilization of micro-credit by the female community: A case study of Azad Jammu and Kashmir, Pakistan. International Journal of Agriculture and Biology 5: 156-80.

Mahmood, Tahir, Muhammad Farooq Arby, Tauqir Hussain, and Abdul Sattar. 2016. Impact of microfinance on income generation and living standards: A case study of Dera Ghazi Khan Division. Pakistan Economic and Social Review 54: 73-80.

Mayoux, Linda. 2001. Impact Assessment of Microfinance: Towards a Sustainable Learning Process. Available online: www.enterprise-impact@org.uk (accessed on 13 June 2020).

Menard, Scott. 1995. Applied Logistic Regression Analysis (Sage University Paper Series on Quantitative Application in the Social Sciences, Series No. 106), 2nd ed. Thousand Oaks: Sage.

Miled, Kamel Bel Hadj, and Jalel-Eddine Ben Rejeb. 2015. Microfinance and poverty reduction: A review and synthesis of empirical evidence. Procedia Social and Behavioral Sciences 195: 705-12. [CrossRef]

Mohammad, A. Khan, and A. Rahaman Mohammed. 2007. Impact of Microfinance on Living Standards, Empowerment and Poverty Alleviation of Poor People: A Case Study on Microfinance in the Chittagong District of Bangladesh. Umeå: Department of Business Administration, Umeå School of Business (USBE), pp. 1-95.

Omoniyi, Mary Banke Iyabo. 2013. The Role of Education in Poverty Alleviation and Economic Development: A theoretical perspective and counselling implications. British Journal of Arts and Social Sciences 15: 176-85.

Park, Albert, and Changqing Ren. 2001. Microfinance with Chinese characteristics. World Development 29 : 39-62. [CrossRef] 
Pervez, Sikander. 2014. Impact of education on poverty reduction: A co-integration analysis for Pakistan. Journal of Research in Economics and International Finance 3: 83-89.

Saad, Ahmad, Imtiaz Ahmad Waraich, and Mariah Ijaz. 2014. Socio-economic effects of microfinance on agricultural sector: An analysis of farmer's standard of life in Multan. International Review of Management and Business Research 3: 1671-82.

Saboor, Abdul, Maqsood Hussain, and Madiha Munir. 2009. Impact of micro credit in alleviating poverty. Pakistan Journal of Life and Social Sciences 7: 90-97.

Simanowitz, Anton. 2003. Appraising the Poverty Outreach of Microfinance: A Review of the CGAP Poverty Assessment Tool (PAT). Occasional Paper 1. Falmer: Impact, Institute of Development Studies.

Swain, Ranjula Bali, and Maria Floro. 2012. Assessing the effect of microfinance on vulnerability and poverty among low income households. The Journal of Development Studies 48: 605-18. [CrossRef]

Waheed, Seemi. 2009. Does rural micro credit improve well-being of borrowers in Punjab, Pakistan? Pakistan Economic and Social Review 47: 31-47.

Weiss, John, Heather Montgomery, and Elvira Kurmanalieva. 2003. Microfinance and Poverty Reduction in Asia: What Is the Evidence? (Research Paper No. 53). Tokyo: Asian Development Bank Institute, Available online: https://www.adb.org/sites/default/files/publication/157225/adbi-rp53.pdf (accessed on 10 June 2020).

World Bank. 2011. World Development Report 2011: Poverty. New York: Oxford University Press.

Yunus, Muhammad. 2001. Banker to the Poor: The Autobiography of Muhammad Yunus, Founder of the Grameen Bank. New York: Oxford University Press.

Zaman, Hassan. 2000. Assessing the Poverty and Vulnerablity Impact of Micro Credit in Bangladesh: A Case Study of $B R A C$. Office of the Chief Economist and Senior Vice President (DECVP). Washington: The World Bank, pp. 34-36.

Government of Pakistan. 2016. Pakistan Economic Survey 2016-2017; Islamabad: Ministry of Finance, Chapter 15.

Pakistan Microfinance Network. 2017. Micro Watch (Issue No. 42). Available online: http://www. microfinanceconnect.info/assets/articles/d34305e0acc6d13f591fa0ddf120445e.pdf (accessed on 10 June 2020).

Robinson, Marguerite S. 2001. The Microfinance Revolution: Sustainable Finance for the Poor. Washington, DC: The World Bank, Available online: http://people.virginia.edu/ \{\}sj8n/research/microfinJELreview.pdf (accessed on 12 June 2020).

(C) 2020 by the authors. Licensee MDPI, Basel, Switzerland. This article is an open access article distributed under the terms and conditions of the Creative Commons Attribution (CC BY) license (http://creativecommons.org/licenses/by/4.0/). 